\title{
Problems and management mechanisms of reproduction of human resources of peripheral rural territories of the Republic of Mordovia
}

\author{
Elena Kovalenko*, Tatiana Polushkina, Tatiana Koroleva, and Olga Yakimova \\ National Research Ogarev Mordovia State University, Saransk, 430005, Russia
}

\begin{abstract}
The article is devoted to the problem of human resourcing in the agricultural sector of the economy which has been aggravated for a long time. The measures taken under the framework of the widespread implementation of the State Program for Development of Agriculture and Regulation of Agricultural Commodity Markets for 2013-2020 contribute to the modernization of the physical infrastructure, growth of agriculture, development of the village social assets, but they do not ensure abatement of depopulation of the rural population and the influx of skilled personnel into the agro-industrial complex. This is facilitated by the lack of a spatial aspect in the programs implemented, insufficient consideration of features, potential and possibilities of self-development of territories that reduces performance and effectiveness of municipal programs. A typology of municipalities of the Republic of Mordovia was carried out on the basis of "center - periphery", demographic situation and economic specialization characteristics. The proposals on improving management of human resources reproduction in municipal territories, in particular, on creating a system for monitoring labor resources and selecting personnel using modern information technologies, as well as on improving the current system for assessing the effectiveness of local governmental activities are formulated.
\end{abstract}

\section{Introduction}

One of the goals of government policy in the Strategy for sustainable development of rural territories of the Russian Federation until 2030 is to increase the efficiency of agriculture and contribution of rural territories to the socio-economic development of the country. The main factor in achieving the goal is the human resources potential intended to ensure labor productivity increase in 1.7 times by the year 2020 and in 3 times by the year 2030 compared with the current level. The quantitative and qualitative condition of the human resources potential determines the opportunities for economic growth and social development of the territory, its competitiveness among regions of the country.

In the condition of regionalization and differentiation of power, strengthening territorial interconnections in the economic space, the reproduction of agriculture human resources potential depends not only on industry characteristics but also on the geographical, demographic, socio-economic conditions for functioning of the countryside that makes it necessary to identify key areas of human resources policy development in accordance with the priorities of the strategic development of a specific territory $[1,2]$.

A critical staffing situation in many rural areas should be noted because of high level of natural and migration loss and aging of the population, reduction in the number of educational institutions and low attractiveness of agricultural labor for young people [3]. Such a conclusion can be made by analyzing official data of state statistics. Thus, the number of the rural population of Russia as of January 1, 2018 amounted to 37.6 million people ( $25.6 \%$ of the total population) and it is reduced annually on average by $0.3 \%$.

The rural population is declining driven by three components: natural loss, migration loss and administrative-territorial transformations. The contribution of each component on average for 20152017 amounted to $53.4,30.0$ and $16.5 \%$, respectively. In the structure of the rural population, the share of the employable (by $3.1 \%$ over the past five years) and skilled population is decreasing. In 2017, the proportion of workers in agriculture with higher education was 11.6 $\%$, with secondary vocational education was $41.3 \%$, while the average for the economy was 33.5 and $45.1 \%$, respectively.

The feature of Russian agriculture is the production structure, in which $55 \%$ falls on agricultural organizations, $12.5 \%$ on farms and $32.5 \%$ on population households. The number of large and medium-sized agricultural organizations over the past ten years has decreased by 3.5 times due to liquidation and merger. The distribution of employees between large and medium-sized organizations and small enterprises

* Corresponding author: kovelena13@mail.ru 
(peasant farms and individual entrepreneurs) is 3:1. As a result of these processes, there is great tension on the labor market in many rural settlements; employment opportunities and choice of vacancies are very limited in rural areas. This is facilitated by the predominance of fine dispersion in rural settlement $-95 \%$ of settlements have fewer than 1000 people, $4.5 \%-1$ to 5 thousand, $0.6 \%$ - over 5 thousand inhabitants)[4].

The modern Russian reality is the technology gap between large agricultural companies and small farms, which is revealed both in labor productivity and in income levels of the population. Over the past three years, the labor productivity has been growing in agriculture annually on average by $5 \%$, which is reflected in the growth of remuneration in the industry. In 2017, the average monthly nominal gross payroll of agricultural workers was amounted to 25.7 thousand rubles; in 2015 it was 20.7 thousand rubles (an increment by $24.2 \%$ ), however, it still remains at the level of $65.5 \%$ of the average level in the economy.

According to the officially accepted estimate, in 2017, the absolute poverty, which is determined by the population with per capita income below the minimum subsistence level, was in densely populated rural areas: up to 1 thousand inhabitants $-30.1 \%$ (45\% of the rural population); 1 to 5 thousand people $-23.9 \%$ (35\% of the rural population); over 5 thousand people $-25.7 \%$ (20\% of the rural population) [4].

This situation creates barriers to reproduction of labor resources in rural areas, replenishment of the country agro-industrial complex with highly qualified employees. The solution of numerous problems requires an active position of the regional state authorities and local governments in managing the human resources reproduction processes in subordinate territories.

Due to its multidimensional nature, the scientists of various sciences are engaged in the study of this prospect: economics, geography, sociology and others. The works of the following geographers are important for a deep understanding of trends and factors of rural transformation: Velikiy (2012), Kryuchkov (1978), Nefedova (2013), Treyvish (2010), Patsiotsirkovskiy (2010), Rakitnikov (1963). The problems of village sociology were studied by Bondarenko (2014), Zaslavskaya (2007), Zubarevich (2017), Savenkova (2015), Khagurov (2012) and others.

Numerous aspects of sustainable development of rural territories are studied both by teams of scientists from research institutes and universities of the country, and by individual scientists, among which the works of the following scientists stand out: Antokhonova (2009), Adukov and Adukova (2011), Lazovsky (2014), Mantino (2010), Merenkova (2011), Merzlov, (2012), Mishchenko (2012), Trotskovsky (2013), Tchaika (2014). The works of Strumilin (1965), Ushachev (2008), Paptsov (2014), Kopylov (2012), Kolobova (2012), Sergienko (2003), Rodionova (2011), Kalugina (2009), Valentey (1999), Ivanova (2017), Ukhobotov (2009), Yakushkin (2017), Sharipov (2014) are devoted to the problems and areas of development of the human resources potential in the agro-industrial complex.
Despite the presence of a significant number of works devoted to the reproduction of human resources in the country's agro-industrial complex, the issues of the influence of spatial changes in the countryside and the government policy of sustainable development of rural areas and their impact on the processes of human capital formation remains insufficiently studied.

The main focus of this study is the substantiation of the types of rural territories by spatial, demographic and economic characteristics, priority tasks and tools for regulating the processes for reproduction of human resources for the agro-industrial complex.

\section{State hypotheses and their correspondence to research design}

The working hypothesis of the study is that the socioeconomic development of rural areas and special attention to the preservation and increase of human capital plays a key role in reliable provision the country agro-industrial complex with highly qualified personnel. The modern approach and the pace of development of rural areas driven by subsidies, minimum state social guarantees and easy-term loans does not allow overcoming the systemic crisis of the village but slows down the process of its stagnation only. Despite the importance of state support for the accelerated technical and technological development of agro-business, the complex factors of the revival of human capital primarily determining decent quality of life of the rural population that is close to modern social standards, are more effective.

\section{Methods}

The theoretical basis of the study was the fundamental and applied works in which the provisions of the theory of spatial development, human capital, institutions and institutional changes are formulated. The methodological basis of the study is the synergetic paradigm that combines and synthesizes systemic and institutional approaches. General scientific methods of theoretical and empirical knowledge were used in the study: methods of analysis and synthesis, methods of classifications and formalization, system, statistical, functional and economic analysis.

The empirical information base of the study consists of statistical data of the Federal State Statistics Service and its territorial body for the Republic of Mordovia, program documents, analytical reports and reports of the Ministry of Agriculture of the Russian Federation, the Ministry of Economy of the Republic of Mordovia, the Ministry of Agriculture and Food of the Republic of Mordovia, analytical reports and reports of municipal authorities, research results of research institutes, analytical data presented in periodicals and on websites.

\section{Results and discussion}

The State Program for Development of Agriculture and Regulation of Agricultural Commodity Markets for 
2013-2020 (hereinafter referred to as the State Program) determine that the average annual growth rate of agricultural production in Russia for the period of 2013-2020 should be at least 2.4-2.5\%. In fact, on average for 2013-2017, it amounted to $3.8 \%$ with significant differentiation by region of the country [5].

In the Republic of Mordovia, for example, this indicator for the same period is $4.6 \%$, which gives reason to consider that the development of the industry is dynamic. For some types of agricultural products, the Republic occupies leading positions in Russia and Volga Federal District (VFD), of which it is part. So, in 2018, in the production of livestock products per capita, Mordovia occupied: the 1st place in Russia and VFD in eggs output, the 2nd place in Russia and the 1st place in VFD in milk output, the 7th place in Russia and the 2nd place in VFD in cattle and poultry meat output. The Republic not only meets in full its consumer demand on the market for meat, milk, eggs, sugar, potatoes and vegetables, but also sells its products to other regions. The share of export by its individual types is 40 to $80 \%$ of production volumes.

The main growth in agricultural production is provided by agricultural organizations, whose share in the total volume increased from $58 \%$ in 2013 to $72 \%$ in 2017. The number of organizations in the industry is reduced by $4-5$ units annually, and since 2005 , according to Mordoviyastat their number decreased almost in 5 times [6]. Less than $1 / 3$ of companies demonstrates growth in production. The segment of small enterprises in the industry is not growing practically, despite formal action of targeted programs of their state support. In 2017, the number of functioning peasant farms amounted to 720 units (of 1.133 created), and no more than $40 \%$ of its number makes a significant contribution to the production volume.

As a result of these processes, hundreds of rural settlements do not have an employing organization, there are no workplaces practically, and the main source of subsistence is a private smallholding. As of January 1, 2018, there were 1,240 rural settlements in Mordovia, 89 of which were with no population, and $66 \%$ of which with population less than 200 people and with a lack of acceptable social comfort of living. $96 \%$ of the rural population of the Republic lives in settlements with less than 1.000 inhabitants and highest probability of absolute poverty. These are the circumstances that lead to the demographic crisis and problems with the reproduction of labor resources in rural areas [7].

The "Promotion of human resources potential in agro-industrial complex" subprogram of the State program of the Republic of Mordovia for Development of Agriculture and Regulation of Agricultural Commodity Markets for 2013-2025 (hereinafter referred to as the subprogram) notes an aggravation of the problem of staffing in agro-industry manifested in the staff aging, lack of tangible infusion of young human resources in agriculture. The staffing of agricultural organizations in specialists averaged $75 \%$, including with higher education - $78 \%$, with secondary specialized education $-72 \%$. Organizations lack $32 \%$ of agronomists, $25 \%$ of livestock specialists, $24 \%$ of veterinarians, $11 \%$ of engineers and $30 \%$ of mechanical technicians.

Over the past 15 years, the number of young specialists has been declining, and in $26 \%$ of municipal districts there are practically no young specialists working in the professions of livestock specialists, veterinarians, agronomists within 3 years after completing vocational education. No more than 6-8\% of graduates of higher educational institutions and specialized secondary educational establishments of agricultural profile remain to work in the village.

To solve this problem, the Republic has developed measures that include: 1) scholarships to students receiving higher or secondary vocational education from the Republican budget (up to 3 and 2 thousand rubles per month respectively from the Republican budget and from 1 thousand rubles from the employer in addition to the state scholarship); 2) grants for young specialists employed in agricultural organizations (300 thousand rubles with higher and 210 thousand rubles with secondary vocational education); 3) monthly allowance for 3 years for young specialists with higher ( 8 thousand rubles) and secondary vocational (6 thousand rubles) education provided that the employer pays wages not lower than the industry average for the previous year. To finance these measures, the following is planned in the Republican budget: 14 million rubles in 2016; 39 million rubles in 2017; 50 million rubles in 2018; 60 million rubles in 2019. In 2016, 254 people became participants in the subprogram, 309 people in 2017 and 348 people in 2018. The volume of the Republican budget funds for financing support measures amounted: in 2016 14 million rubles; in 2017 - 22 million rubles; in 2018 39 million rubles. [8].

It should be noted that participation in the subprogram requires fulfillment of obligations not only by government bodies, but also by agricultural organizations and support recipients - students and young specialists. Considering that more than a thousand students enter the agricultural specialties annually, the share of those participating in the subprogram does not exceed $5 \%$, and more than $50 \%$ of the vacancies currently offered to specialists by agricultural organizations offers wages significantly lower than the industry average (12-15 thousand rubles against 23 thousand rubles average for 2016-2017). Large enterprises, setting wages at the level of 30-50 thousand rubles, invite employees with experience, therefore they do not seek to participate in the subprogram, and medium and small farms cannot guarantee high wages due to the low level of production profitability.

These circumstances do not contribute yet to the achievement of target indicators for increasing the share of qualified specialists in agricultural production up to $85 \%$, and young specialists in their total number are of $10 \%$, therefore, the degree of their achievement is not indicated in any of the annual reports on the State program implementation.

One of the significant weaknesses of the targeted programs being implemented is the lack of a spatial aspect, both in the state of a regulated object and in 
measures to eliminate existing problems. In the vast majority of them, the municipalities (districts, urban districts) within the subject of the Russian Federation are not represented in expanded form, and the system of support measures is unified, therefore, it does not reach the planned performance upon implementation.

This fully applies to the problem of developing the human resources potential in agro-industrial complex. The spatial aspects of the demographic state of municipalities of the Republic of Mordovia, as well as the average per capita values of selected economic indicators are shown in Table 1. In Mordovia, there is one large city only. It is Saransk, the capital of the Republic.

The study conducted the typology of municipal districts according to the radius of remoteness from the center in order to establish the degree of the urban influence on the demographic situation and the development of agriculture according to the method proposed by the team of Altai scientists [9].

Table 1. Spatial aspect of the demographic status of municipalities of the Republic of Mordovia in 2017.

\begin{tabular}{|c|c|c|c|c|c|c|c|}
\hline \multirow{2}{*}{$\begin{array}{l}\text { Municipal districts (MD) } \\
\text { and urban district (UD) }\end{array}$} & \multirow{2}{*}{$\begin{array}{l}\text { Population } \\
\text { density, } \\
\text { people per } \\
1 \mathrm{~km}^{2}\end{array}$} & \multirow{2}{*}{$\begin{array}{l}\text { Number of } \\
\text { population, } \\
\text { thousand } \\
\text { people }\end{array}$} & \multirow{2}{*}{$\begin{array}{l}\text { Share of } \\
\text { rural } \\
\text { populatio } \\
\text { n, } \%\end{array}$} & \multicolumn{2}{|c|}{$\begin{array}{c}\text { Population size increment } \\
\text { rate, } \% \text { o }\end{array}$} & \multicolumn{2}{|c|}{$\begin{array}{c}\text { Per capita, } \\
\text { thousand roubles }\end{array}$} \\
\hline & & & & natural & migratory & $\begin{array}{l}\text { agricultural } \\
\text { products }\end{array}$ & $\begin{array}{c}\text { own budget } \\
\text { revenues }\end{array}$ \\
\hline UD Saransk Center & 909.6 & 346.4 & 2.4 & -0.53 & 12.06 & 7.4 & 8.5 \\
\hline \multicolumn{8}{|c|}{ Near periphery of the 1 st order with a radius of up to $40 \mathrm{~km}(127.7$ thousand people $-15.8 \%)$} \\
\hline Lyambirsky MD & 38.9 & 34.3 & 100.0 & -4.4 & 1.1 & 290.7 & 4.4 \\
\hline Kochkurovsky MD & 12.1 & 9.9 & 100.0 & -11.4 & 8.8 & 146.3 & 4.5 \\
\hline Romodanovsky MD & 25.0 & 19.6 & 100.0 & -6.2 & -5.8 & 112.6 & 5.4 \\
\hline Ruzayevsky MD & 56.7 & 63.9 & 28.4 & -5.5 & -11.6 & 52.0 & 4.1 \\
\hline MD group average & 37.6 & 31.9 & 64.4 & -1.9 & 7.3 & 132.7 & 4.4 \\
\hline \multicolumn{8}{|c|}{ Near periphery of the 2 nd order with a radius of 30 to $80 \mathrm{~km}(92.4$ thousand people $-11.45 \%)$} \\
\hline Bolshebereznikovsky & 13.0 & 12.5 & 100.0 & -16.9 & 1.3 & 55.6 & 3.4 \\
\hline Insarsky MD & 12.6 & 12.3 & 33.8 & -10.5 & -13.7 & 115.2 & 4.2 \\
\hline Ichalkovsky MD & 14.4 & 18.4 & 100.0 & -8.3 & -6.6 & 152.8 & 4.7 \\
\hline Kadoshkinsky MD & 11.0 & 6.9 & 37.3 & -9.0 & -18.4 & 142.5 & 4.6 \\
\hline Staroshaigovsky MD & 8.4 & 12.0 & 100.0 & -10.3 & -12.6 & 162.6 & 4.1 \\
\hline Chamzinsky MD & 29.8 & 30.3 & 27.1 & -5.0 & -3.1 & 394.0 & 5.1 \\
\hline MD group average & 14.7 & 15.4 & 60.7 & -9.0 & -7.0 & 214.2 & 4.5 \\
\hline \multicolumn{8}{|c|}{ Near periphery of the 1 st order with a radius of 81 to $150 \mathrm{~km}(123.9$ thousand people $-15.4 \%)$} \\
\hline Ardatovsky MD & 21.1 & 25.4 & 46.6 & -12.6 & -7.2 & 76.6 & 3.0 \\
\hline Atyashevsky MD & 15.7 & 17.4 & 63.7 & -9.5 & -8.4 & 187.8 & 6.8 \\
\hline Bolsheignatovsky & 8.3 & 7.0 & 100.0 & -8.9 & -5.7 & 131.8 & 3.5 \\
\hline Dubensky MD & 13.1 & 11.9 & 100.0 & -11.3 & -13.6 & 154.5 & 4.4 \\
\hline Kovylkinskiy MD & 18.9 & 38.9 & 49.0 & -8.8 & -21.1 & 105.1 & 5.0 \\
\hline Krasnoslobodsky MD & 16.7 & 23.3 & 59.1 & -9.3 & -9.7 & 102.0 & 4.1 \\
\hline MD group average & 16.7 & 20.6 & 58.1 & -10.0 & -12.7 & 116.5 & 4.5 \\
\hline \multicolumn{8}{|c|}{ Near periphery of the 2 nd order with a radius of 131 to $180 \mathrm{~km}(51$ thousand people $-6.3 \%)$} \\
\hline Atyurevsky MD & 9.7 & 8.2 & 100.0 & -8.8 & -26.7 & 99.7 & 3.7 \\
\hline Elnikovsky MD & 9.2 & 9.9 & 100.0 & -11.2 & -16.4 & 85.4 & 3.5 \\
\hline Temnikovsky MD & 7.2 & 14.1 & 55.5 & -15.1 & -9.6 & 72.0 & 5.4 \\
\hline Torbeevsky MD & 16.9 & 18.8 & 51.8 & -6.5 & -7.8 & 58.0 & 4.7 \\
\hline MD group average & 10.4 & 12.8 & 66.8 & -10.2 & -13.0 & 73.9 & 4.5 \\
\hline \multicolumn{8}{|c|}{ Far periphery with a radius of $181 \mathrm{~km}(65.5$ thousand people $-8.1 \%)$} \\
\hline Zubovo-Polyansky MD & 20.3 & 55.1 & 55.6 & -6.7 & 0.4 & 25.1 & 4.6 \\
\hline Tengushevsky MD & 12.2 & 10.4 & 100.0 & -12.0 & -5.4 & 77.3 & 7.9 \\
\hline MD group average & 19.5 & 32.7 & 61.4 & -7.5 & -0.5 & 33.4 & 5.1 \\
\hline Republic of Mordovia & 30.8 & 35.1 & 36.6 & -5.0 & 0.6 & 75.7 & 6.4 \\
\hline
\end{tabular}

To solve the problem of agricultural human resources reproduction, it is important to evaluate the types of municipal districts by the periphery and demographic situation. The calculations show that depending on the distance from the center, the total population decline increases from $5.4 \mathrm{ppm}$ in the zone of the near periphery of the 1 st order to $23.2 \mathrm{ppm}$ in the zone of the middle periphery of the 2 nd order (increases in 4.3 times).

An exception to this regularity is the zone of the far periphery, which includes Zubovo-Polyansky and Tengushevsky municipal districts, the territories of which are 66.1 and $40.8 \%$ respectively represented by forest lands (their average share in the Republic is
$25.2 \%$ ). In 11 of 23 represented municipalities of Mordovia, only the rural population lives, and its share in 5 remaining municipalities is more than $50 \%$. The crisis demographic situation is typical for $2 / 3$ of the municipal districts, in which the natural basis for the reproduction of labor resources for many settlements no longer exists.

The agrarian sector is represented to varying degrees in all municipalities, that can be judged by the indicator of agricultural production in current prices per capita: in 17 municipal districts (74\% of the total), it is higher than average in the Republic. The agro-industrial complex specialization is agricultural in 4 districts only, 
in the remaining 19 districts it is agricultural-industrial. The urban district of Saransk, Ruzayevsky and Chamzinsky municipal districts have mainly industrial specialization of the economy.

The economic specialization of the territories has a significant impact on the number and variety of work places, material well-being of the population, mood of residents to live and work at homeland, or to migrate to larger and more comfortable settlements. All these factors should be taken into account in the management of the reproduction of human resources in the municipal territory.

An analysis of the content of the strategies for the socio-economic development of municipalities (districts and urban district) until 2025, which were accepted for implementation, as a rule, in 2018, allows stating that the sections on labor resources are developed formally; they do not contain measures capable to change the crisis situation. The needs of the territories can be satisfied by no more than 5-6\% at the expense of young specialists (according to the survey), since the probability of working in rural areas of the Republic is considered only by $6-7 \%$ of university graduates, $7-9 \%$ of secondary specialized institutions and no more than 10-15\% of vocational institutions.

This implies the need to identify areas for improving provision of the agricultural sector of the economy with qualified specialists, to form focused policy in the field of demography, education and social sphere by improving regulatory framework and organizational and economic mechanism of human resources reproduction. The design of the necessary package of measures should be carried out using the basic principles of strategic planning $[10,11]$.

It should be noted that many areas of solving the human resources problems in the rural sector are reflected in strategic documents, but the paces and scales, as well as the internal capabilities of municipalities do not contribute to their solving in the foreseeable future. Among these areas, for example, the development of the village social assets, improvement of the training and skill enhancement system for agricultural personnel, integration of educational institutions and agro-business enterprises and many others.

In our opinion, it is necessary to strengthen two functions in the system for managing the human resources reproduction in rural areas: analytical and control ones. The analytical function can be ensured by the creation of a system in the region for monitoring labor resources and staff recruitment using modern information technologies. The data base that integrates state and municipal government structures, educational institutions, enterprises and territorial organizations into its system should be formed in the Internet.

The system should provide a wide range of information and update data banks on the situation in the rural labor market and the reserve of agro-business managerial personnel, the system should regularly generate analytical reports [12].

Thus, the process of developing and implementing regional and municipal targeted programs for agro- business staffing filled with relevant information can become an effective tool for the program-project approach, can contribute to the improvement of targeted training of specialists and facilitate their employment in the agricultural sector of the economy.

The controlling function can be integrated into the existing system for assessing the effectiveness of local government activities, which is carried out under the framework of the Decree of the President of the Russian Federation dated April 28, 2008 No. 607 "On assessing the effectiveness of local government activities in urban districts and municipalities." The current methodology is unified, it lacks independence of local governments in the selection of key performance indicators of their own activities, which makes the entire evaluation process a formal process aimed at improving positions in a given coordinate system, but not at increasing work efficiency.

In our opinion, among the key performance indicators, natural and migratory gain of population and employment of young specialists in the territory under their jurisdiction should be. This will increase the responsibility of the heads of municipalities for the demographic condition and reproduction of human resources and it will contribute to the formation of new mechanisms for inter-sectoral interaction for the sustainable development of municipalities.

\section{Conclusion}

In Russia, ambitious national goals and objectives for improving the population well-being and economic development, in implementation of which all regions of the country should participate, are outlined for the coming years. The main factor of development is human resources potential, its adequacy and qualifications. For the agricultural sector of the economy, the reproduction of highly qualified human resources in many territories of the country is one of the main problems associated with difficult working conditions, low wages and development of social sphere of rural territories. In these conditions, it is necessary to formulate regional and municipal government policy for the development of personnel potential, which should take into account specific features of the territory that reduce effectiveness of state programs implemented. In managing human resources reproduction, it is necessary to organize monitoring of labor resources and personnel selection involving modern information technologies, as well as to improve the mechanism for assessing the effectiveness of local government activities driven by substantiation of key indicators of spatial development effectiveness of the territory under their jurisdiction.

\section{Acknowledgments}

The study was carried out with the financial support of the Russian Federal Property Fund and the Government of the Republic of Mordovia under the framework of scientific project No. 18-410-130002. 


\section{References}

1. T.L. Besser, New economy businesses in rural, urban, and metropolitan locations, Rural sociology, 68, 531-553 (2003) Retrieved from: https://doi.org/10.1111/j.1549-0831.2003.tb00150.x

2. P. Courtney, L. Mayfield, R. Tranter, P. Jones, A. Errington, Small towns as 'sub-poles' in English rural development: Investigating rural-urban linkages using sub-regional social accounting matrices, GEOFORUM, 38, 1219-1232 (2007) Retrieved from: https://doi.org/10.1016/j.geoforum. 2007.03.006

3. M. Šajbidorová, Z. Lušňáková, M. Dobišová, Management of human resources in agricultural sector enterprises, in Mater. Int. Conf. Sci. days 2016, "The Agri-Food Value Chain, Challenges for Natural Resources Management and Society" (2016) Retrieved from: https://spu.fem.uniag.sk/ mvd2016/proceedings/en/articles/s3/sajbidorova_do bisova_lusnakova.pdf

4. L. Prokofieva, I. Korchagina, Socio-demographic risk groups for poverty and social exclusion, in Mater. Conf. "Poverty of urban and rural population in Russia and France” (Moscow, 2018) Retrieved from: https://isp.hse.ru/data/2018/11/01/ 1142579138/Prokofieva_RU.pdf

5. The State Program for Development of Agriculture and Regulation of Agricultural Commodity Markets for 2013-2020, Retrieved from: http://government. $\mathrm{ru} /$ docs/all/83508/
6. Territorial body of the Federal State Statistics Service for the Republic of Mordovia, Retrieved from: http://mrd.gks.ru/

7. Stat. yearbook (Mordoviyastat, Mordovia, 2018)

8. State program of the Republic of Mordovia for Development of Agriculture and Regulation of Agricultural Commodity Markets for 2013-2025, Retrieved from: http://ivo.garant.ru/\#/document/ 9081125/entry/900:0

9. A.Ya. Trotskovsky, ed., Sustainable development of rural territories of the Altai Territory: socioeconomic and spatial aspects (Barnaul, 2013)

10. T.M. Polushkina, Formation of a rational system of state regulation of the agricultural sector of the economy that meets the requirements of a costeffective agricultural policy, Fundam. Res., 9, 976-980 (2012)

11. E.G. Kovalenko, T.M. Polushkina, I.I. Igaikina, O.Yu. Yakimova, Competitiveness of rural areas due to development of organic agriculture, Advan. in Econ., Busin. and Managem. Res., 38 (2017) Retrieved from: /http://www.atlantis-press.com/ proceedings/ttiess-17/25885460

12. R. Eriksson, H. Hansen, L. Winther, Employment growth and regional development: industrial change and contextual differences between Denmark and Sweden, Europ. Plann. Studies, 25, 1756-1778 (2017) Retrieved from: https://doi.org/10.1080/ 09654313.2017 .1338673 